\title{
Contribution to the Innervation of the Human Uterus.
}

\author{
人子宮の神経分布に関する所見補遺.
}

Kenzo YAMAGATA and Takanaru NAKAMURA 山形健三と村敬愛.

(Received May 23, 1959.)

Many histological studies on the innervation of the uterus have been conducted since olden times. In these studies, various problems have been discussed from a biological and clinical point of view, that is, 1. motor innervation of the uterine musculature in respect to uterine movements, 2. vascular innervation in respect to a local circulatory failure, 3. nerve supply in the endometrium, especially the efferent nerves of uterine glands and sensory nerves, and 4. intra- and extramural nerve plexuses and ganglia.

Despite many detailed discriptions of these structures, no final conclusion seems to have been agreed upon. As for the vegetative innervation of the uterine muscle, KOPPEN $(1950,1952)$ reported, in his studies on the human uterus, that the vegetative nerve periphery formed the terminal reticulum which was in contact with the surface of smooth muscle cells. In these studies, he used the silver method of GROS-SCHULZE. JABONERO (1953) who had investigated the human uterus on a pyridin-silver method claimed that a net of the distal nervous syncytium invaded the uterine wall and formed his so-called 'plexiform synapse à distance' with the effector cells. DUPPROY (1954) and PALLIE, CORNER \& WIDDLE (1954), using methylene blue stain and the silver method of NONIDEZ respectively, observed free motor endings with small terminal enlargements in the uterine muscles of rabbits, women, and still-borns. It seems quite probable that varying techniques employed by the above authors might have resulted in disagreement of their interpretations on vegetative innervation.

SUZUKI (1952) has recently reported an improved silver impregnation method of nervous elements, which minutely demonstrates not only neurofibrillar but also protoplasmic structures. The present paper deals with morphological features of the nerve periphery in human uteri impregnated with SUZUKI's method.

\section{Material and Methods.}

The material used in this study consisted of two surgically extirpated human uteri. One of them was supravaginally resected from a nulliparous woman aged 53 years who had undergone right ovariectomy because of a large cystoma. The uterus was normal in size and shape, and was suggestive of slight chronic endometritis. Another material was taken from the non-pregnant horn of a bicornate uterus at fifth month of pregnancy. It was free from any pathological findings.

The material was fixed immediately after removal in a $20 \%$ formalin solution 
for three months at least. Frozen sections $20-30 \mu$ thick, and serial celloidine sections $15-20 \mu$, thus prepared were stored in a $50 \%$ formalin solution over night. They were processed following SUZUKI's silver impregnation method.

SUZUKI's method employed was as follows: After a treatment with a bicarbonate-urotropin-formalin mixture (B. U. F.) and a 5 to 10 minutes' washing in distilled water (less than 10 minutes), the sections were immersed in a $17 \%$ silvernitrate bath for about an hour. They were then passed through three changes of distilled water, the first change containing $5 \%$ of formalin. Then, they were placed in an ammoniacal silver-nitrate bath. After 30 to 60 minutes, they were transferred into a $10 \%$ cool solution of SEGNET's salt and washed for one minute, and then brought into an identical but warm (about $30^{\circ} \mathrm{C}$ ) solution. The reduction of silver salt which had developed in the former solution was completed in $1 / 4$ to two hours. After a thorough washing with water, a gold-toning was performed with a mixture of $10 \mathrm{gm}$ of ammonium thiocyanate and $10 \mathrm{gm}$ of sodium sulphite with $100 \mathrm{cc}$ of distilled water, and then with $10 \mathrm{cc}$ of $1 \%$ gold chloride solution for about 20 minutes. The gold toning is optional and has advantage of conspicuous visualization. Finally, the sections were dehydrated, after being thoroughly washed in water, in alcohol of increased strength up to $96 \%$, cleared in carbol-xylol and mounted in balsam. In some cases, the cytoplasm and connective tissue fibers were stained with eosine, azan or other aniline dyes subsequent to the gold-toning and washing. These stains proved useful in demonstrating morphological relations between the nerve periphery and other tissue structures.

To make an ammoinacal silver bath, 5 cc of $17 \%$ silver nitrate solution was taken into a test tube of an adequate size, to which caustic ammonia was added drop by drop until the precipitate initially produced was completely dissolved, and then another two drops of ammonia were added. The composition of the B. U. F. -mixture was as follows: formalin (officinal) $30 \mathrm{cc}$, saturated aquaous solution of sodium bicarbonate $70 \mathrm{cc}$, urotropin $13 \mathrm{gm}$.

\section{Results.}

Nerve fibers distributed in the uterus are mostly issued from the plexus uterovaginalis which is located around the cervix uteri. However, during the present study which was carried about with supravaginally extirpated materials, no plexus was located.

The nerve fiber bundles in the uterine wall generally consisted of various numbers of thin numyelinated fibers. It was not seldom, however, that they were associated with one or more coarse unmyelinated fibers (Fig. 1). Generally, the bundles of relatively large caliber run parallel with the blood vessels. In their course, they were divided and reunited repeatedly to form a network of meshes irregular in size and shape. Owing to a complicated, intermingled arrangement of the uterine muscle bundles, the above nerve nets were so complicatedly distributed that a whole view was hardly presented in one section. These nerve fiber bundles were divided again and again to become finally a number of single fibers, mostly running among the muscle fibers, or through the connective tissue (Fig. 2). Besides, they were occasion- 


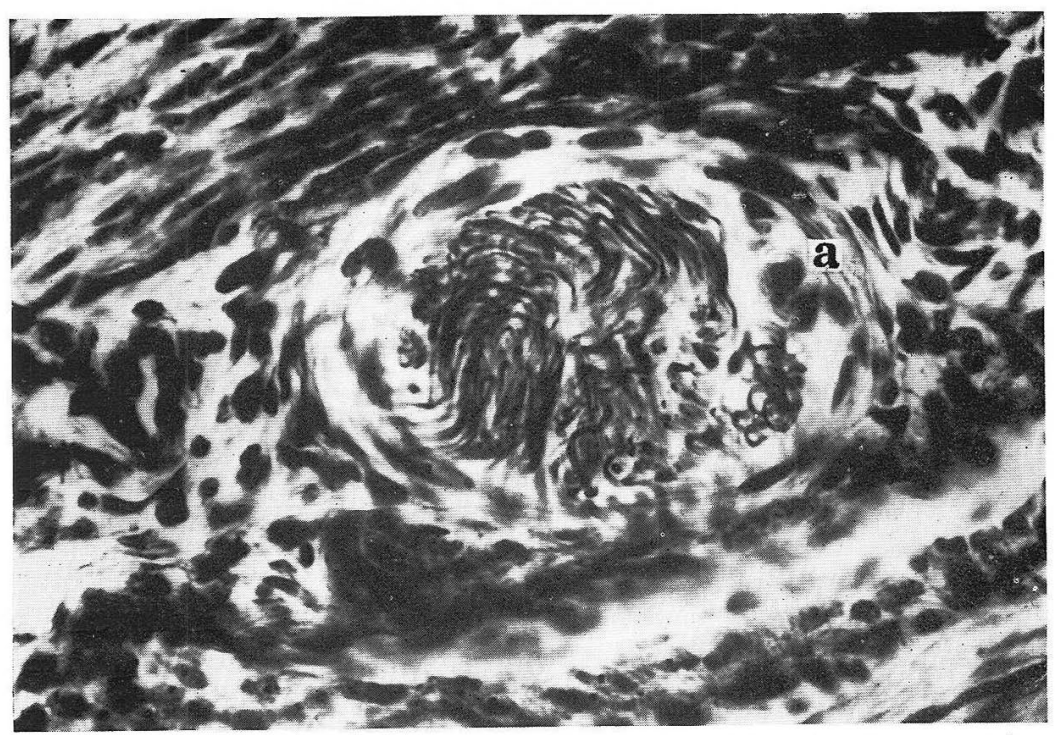

Fig. 1. Photomicrograph of sectiou through the myometrium, to show a cross section of a large bundle of unmyelinated nerve fibers which is followed by an arteriole $(a)$ and enclosed by a well developed connective tissue sheath.

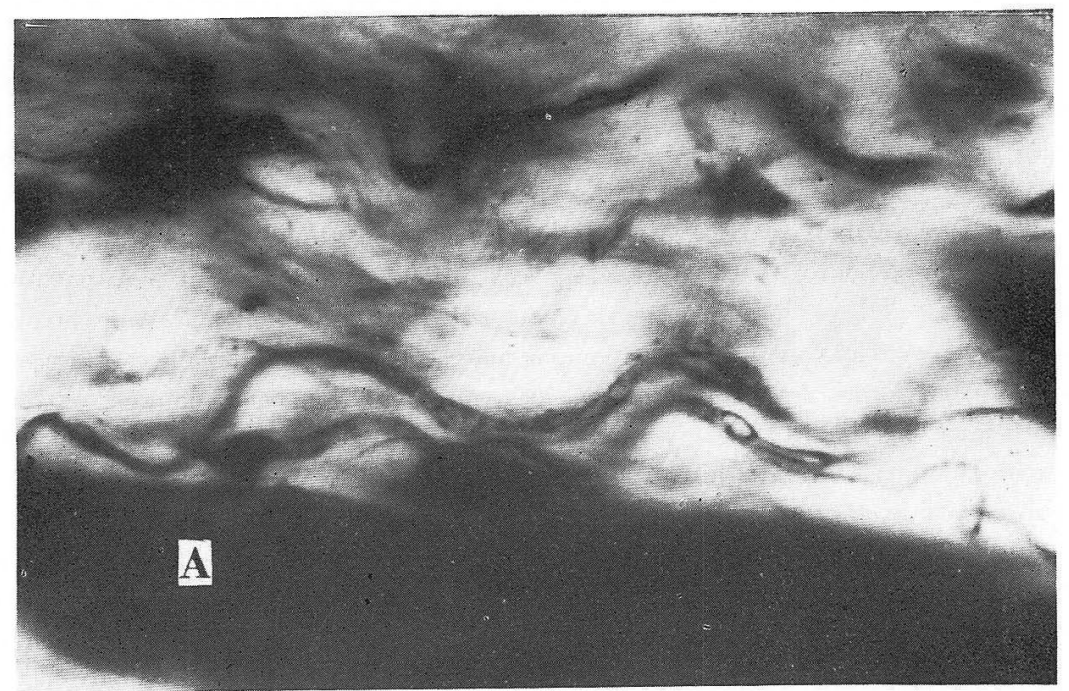

Fig. 2. Photomicrograph of section through the periarterial loose connective tissue, in which a several unmyelinated nerve fibers with beads and vacuoles within them are found to pass through describing gentle curves. $A$ artery.

ally found to enter the myometrium. These single fibers generally reunited each other and gave rise to a terminal reticulum of relatively coarse meshes (Fig. 3). Each nerve fiber involved a protoplasmic band of more or less argyrophilic nature. 


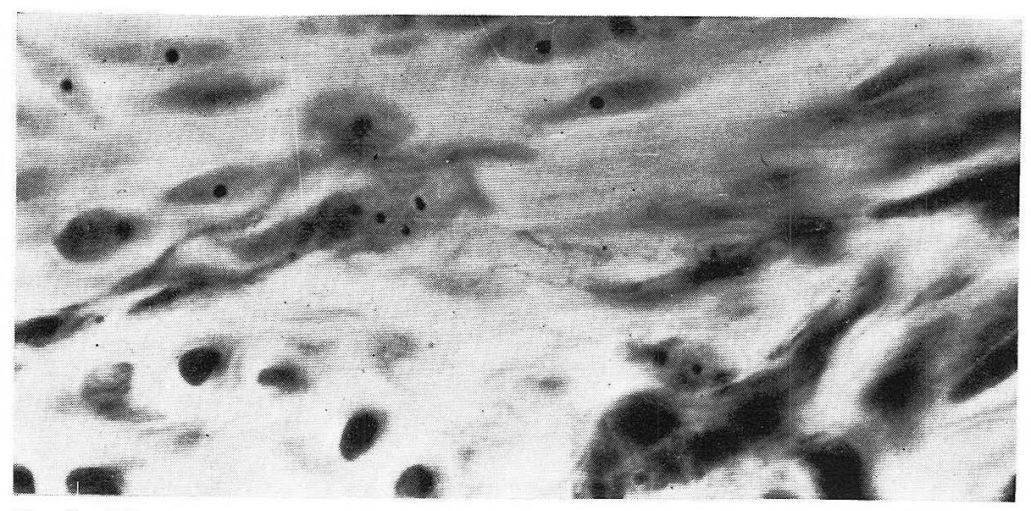

Fig. 3. Photomicrograph of section of the myometrium. A terminal reticulum is shown.

The band contained one or more neurofibrils and scattering nuclei of SCHWANN. In the nerve fiber, the neurofibrils run either parallelly or interwindingly, or anastomosed each other to form a neurofibrillar strand of a reticular structure (Fig. 2). In the neuroplasm, there were found often various granules and vacuoles along or independently of their neurofibrils. The granules were more argyrophilic than the surrounding neuroplasm (Fig. 2). It is not necessarily confirmed as JABONERO (1953) asserted that the more the degree of neuroplasmic argy rophilia the less degree of neurofibrillar differentiation.

Along the course of the nerve strands, there were found of ten triangular or multipolar cells with oval nuclei. These cells showed the vacuolated cytoplasm of argyrophilic nature of various degrees and one or more thin, flattened, protoplasmic processes, which were run through by fine neurofibrils originating from the nerve band. The neurofibrils were eventually interlaced intracellularly to form an irregular network. These neurofibrils were featured by a few beads formed on their pathway. Some of these cells enclosed the nerve fibers within their cytoplasm. And the other occured in syncytial continuity with onc or more strands through their cell processes. On the other hand, some of the proccesses were found to be in contact with the smooth muscle cells. In this way, such a stellate cell formed an intermediate element between the nerve strand and the smooth muscle cells. Hence, it was comparable to the interstitial cells of CAJAL (Fig. 4).

Beside this type of innervation, thin flattened processes of the protoplasmic sheath of the nerve fibers often left neurofibrillar strands and, spreading among the smooth muscle fibers or through connective tissue space, came into a direct contact with the smooth muscle cells of the intrinsic uterine muscle or the muscular coat of the arterioles (Fig. 5). Such mode of efferent innervation appears to correspond to that of the 'periterminal network' of BOEKE.

In the uterus, as well as in other organs, the blood vessels, particularly the arteries, were generally followed by the nerve plexuses consisting of a few unmyelinated fiber-bundles or individual fibers. These plexuse often issued fine collaterals which enter the tunica media to form the secondary nerve plexus among the smooth 


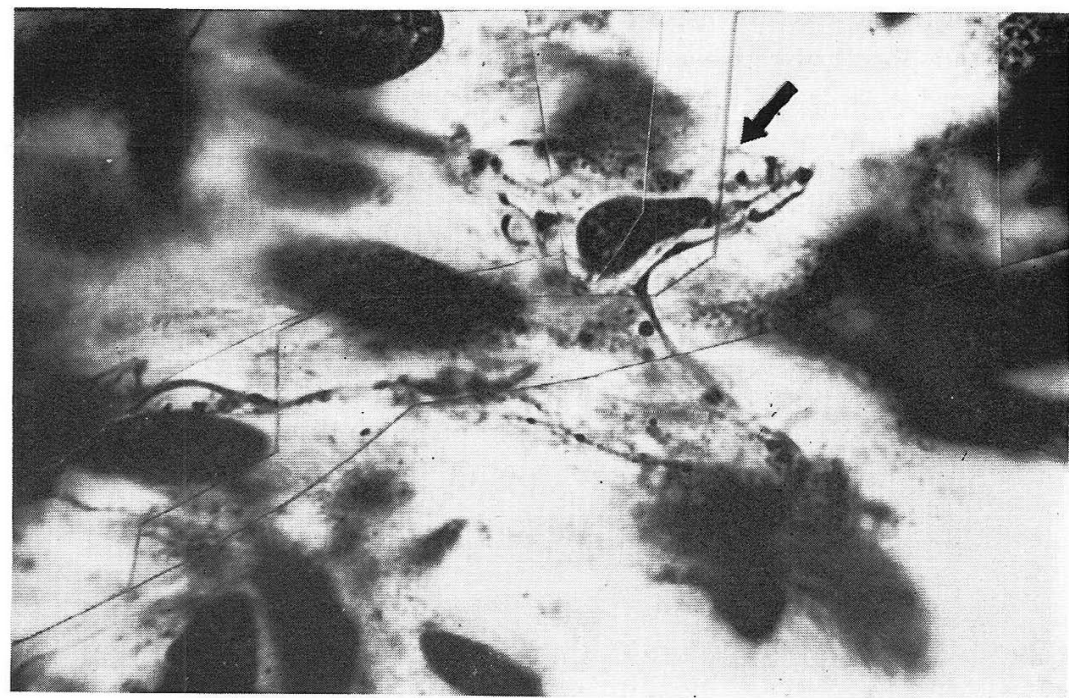

Fig. 4. Montage of 6 abjacent photomicrographs of different optical sections in the same visual field in a section through the uterine muscle. The arrow indicates an interstitial cell of triangular shape lying at the end of the neurofibrillar strand. In the cytoplasm of the former, coarser and finer neurofibrils anastomose with each other to form a network. Intracellular granules and vacuoles along or independent of the neurofibrils are also visible.

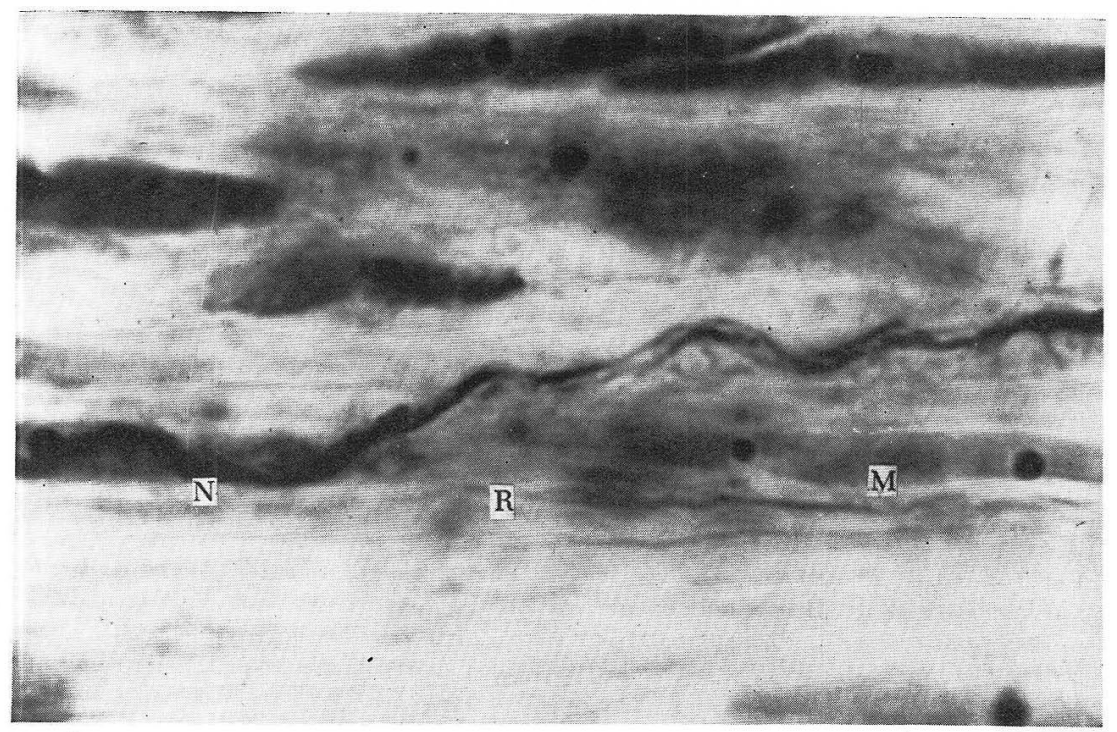

Fig. 5. Photomicrograph of section through the myometrium. Protoplasmic sheath of a nerve fiver $(N)$ spreads as a thin flattened expansion of reticulated structure viz., "periterminal network' $(R)$ which projects to come into contact with a smooth muscle cell $(\boldsymbol{M})$. 
muscle cells. The constituting neurofibrillar strands were always enclosed by the protoplasmic sheath with elongated nuclei therein. These protoplasmic sheaths sometimes seemed to be in contact with the smooth muscle cells(Fig. 6 A-B).

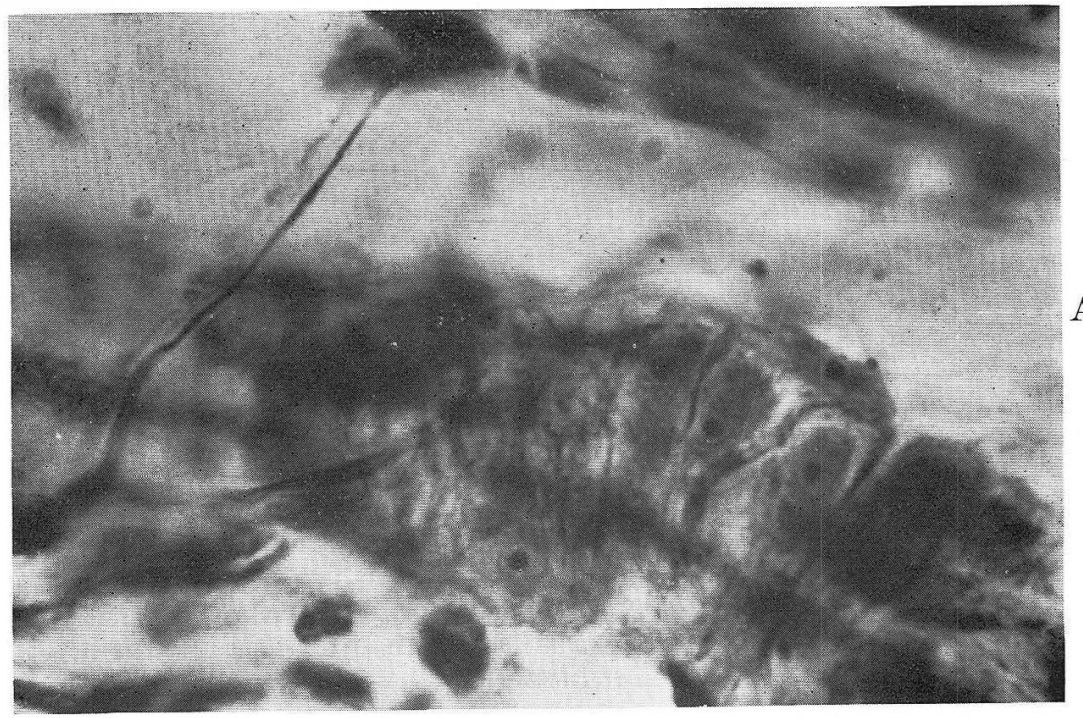

A

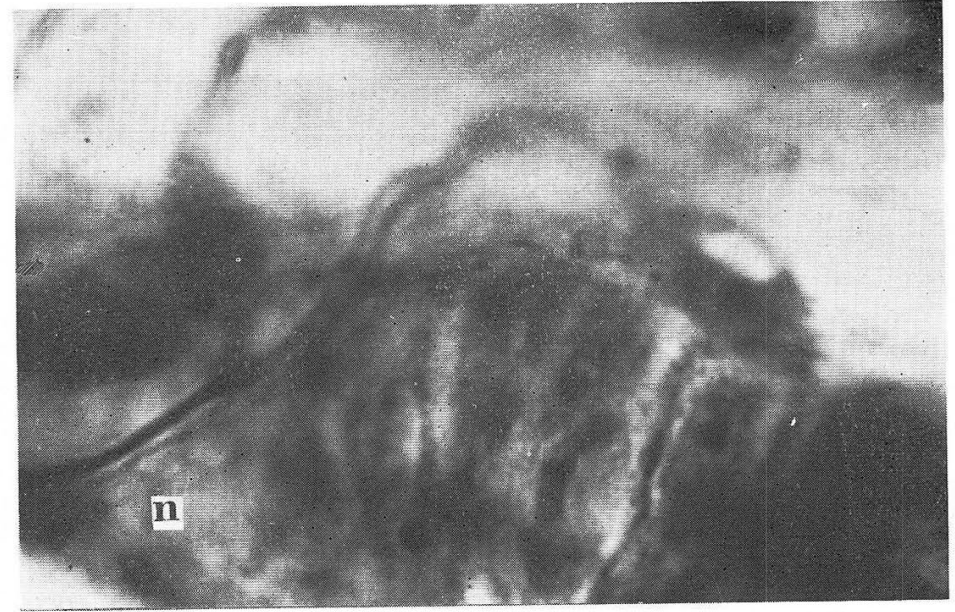

B

Fig. 6 A and B. Photomicrograph of a longitudinal section of an arteriole and its vegetative nerve ending. $\mathbf{B}$ is a high magnification of the same. From a nerve strand $(n)$ consisting of coarser and reticulated finer neurofibrils arises a fine branch with some beads. The branch follows the arteriolar wall for a short distance to end under cover of the cell-body of an adventitial cell. The latter presents two dark-stained long cell-processes which descend among the smooth muscle cells of the media.

Occasionally a stellate cell was found situating between the nerve band and the artery of relatively small caliber. While it communicated with the nerve, it exten- 


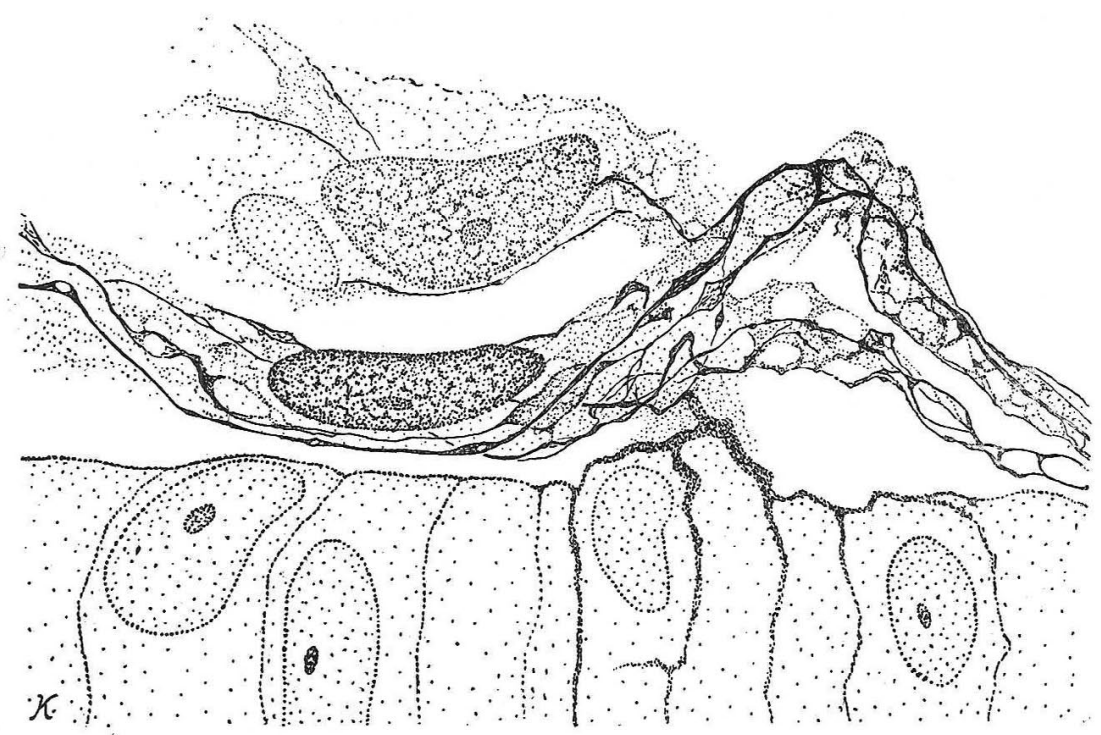

Fig. 7. Efferent innervation of an arteriole. Note the protoplasmic process which, after leaving the unmyelinated fiber, reaches the surface of the muscular coat of the arteriole and comes into an intimate connection with the latter.

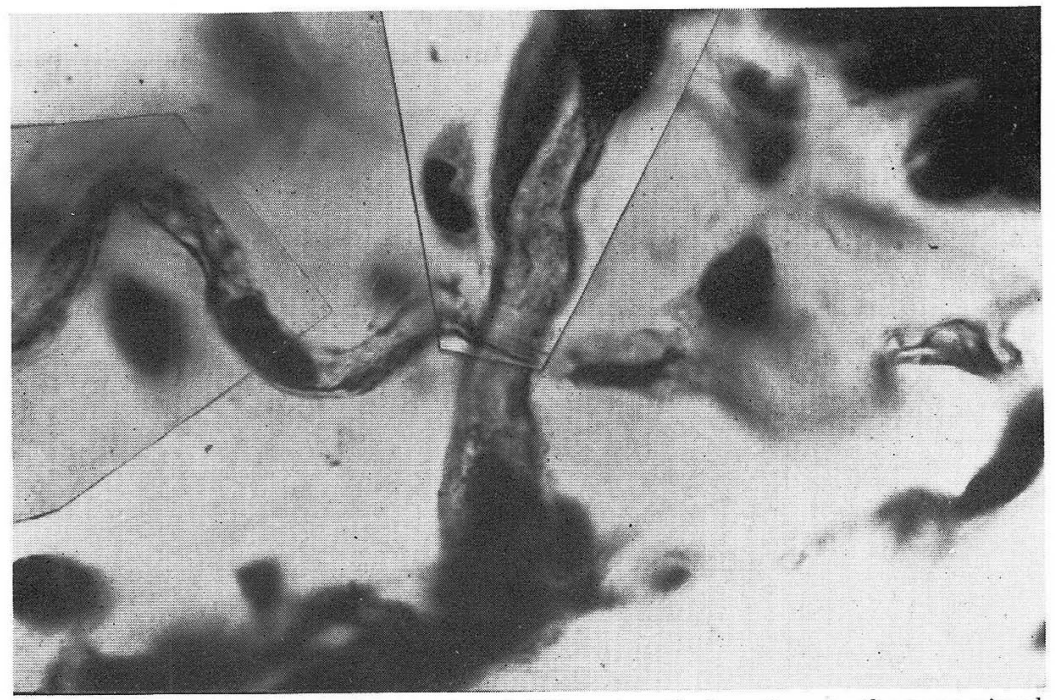

Fig. 8. Composite of photomicrographs of different optical sections in the same visual field in the section through the mymetrium, showing a close relation between a blood capillary and a vegetative nerve fiber. The latter presents within its protoplasmic strand a few elongated nuclei and some interwinding neurofibrils marked by reticulated swellings and, at the site of its crossing over the capillary, comes into a close contact with the capillary wall. At this point, a spindle-shaped cell occurs in a syncytial connection with the protoplasm enclosing the neurofibrils by means of its cellprocess. 
ded its process into the muscular coat of the artery (Fig. 7).

Blood capillaries in the uterus often indicated nerve fibers running parallel to or transversing them. Fig. 8 shows one of the most intimate relations which were found between the nerve periphery and a capillary. A single unmyelinated nerve fiber, crossing over a capillary, came into a direct contact with the latter. A spindleshaped cell in their immediate vicinity extended with its cell process to connect with the capillary wall as well as the protoplasmic sheath of the nerve fiber. In this relation, the above mentioned cell might be regarded to be an essential element of the nervous periphery, i. e., an interstitial cell. In such a particular case, however, it might be more plausible to regard the cell as one of the wandering cells which originally possessed with a stereotropic property. Moreover, as for the siginificance of the nerve fiber for the capillary, Nelemans considered that the nervous syncytium crossing over capillaries does not constitute a true innervation of capillaries. In this study, a light might be shed, on a morphological basis, to an approach to a possible relationship between the nerve and the blcod capillary.

Large nerve fiber bundles passing through the myometrium of ten entered the endometrium and run along the endo-myometrial boundary, and again found their way to the endometrium (Fig. 9 to 12). In a tangential section through the endomyometrial junction, these bundles did not show a plexiform arrangement, but show a rather loose and random communication. Fine collaterals, however, arose from these bundles and formed delicate networks in the endometrium. These networks were observed to diffusely spread out through the propria encircling the uterine glands (Fig. 14, 15). Sometimes, they were found also in the functional layer of the

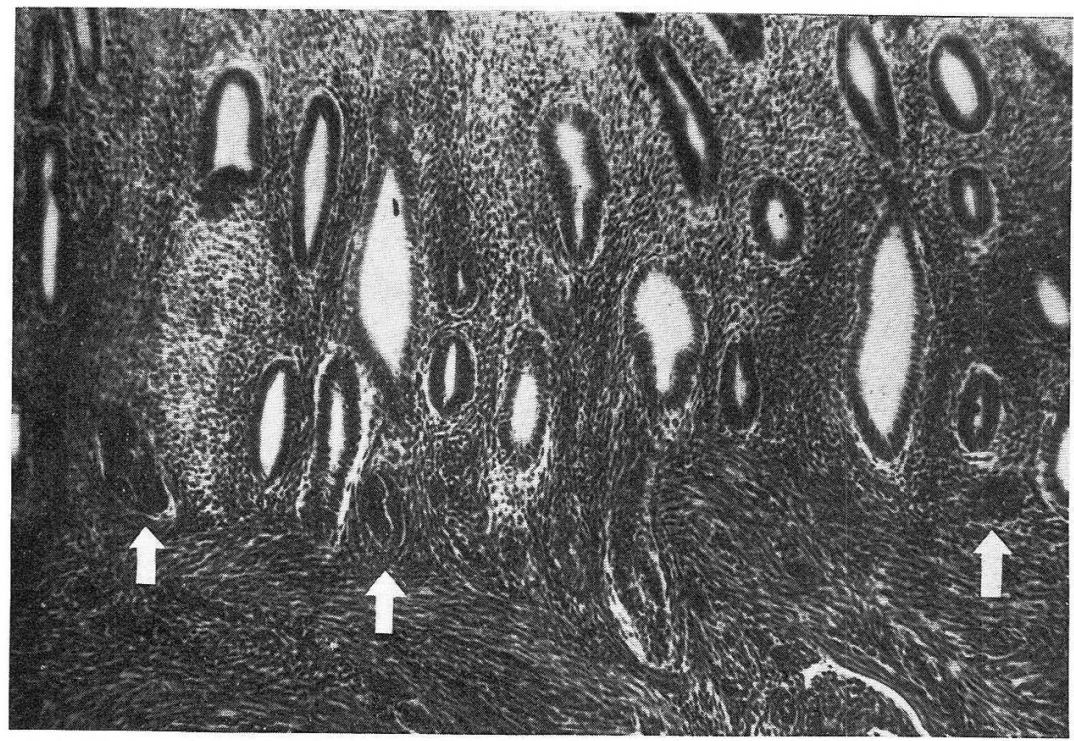

Fig. 9. Lower photomicrograph of perpendicular section through the endometrium. Along the boundary between the endo- and myometrium, three bundles of unmyelinated never fibers are seen cut transversely. The arrows indicate the bundles. 


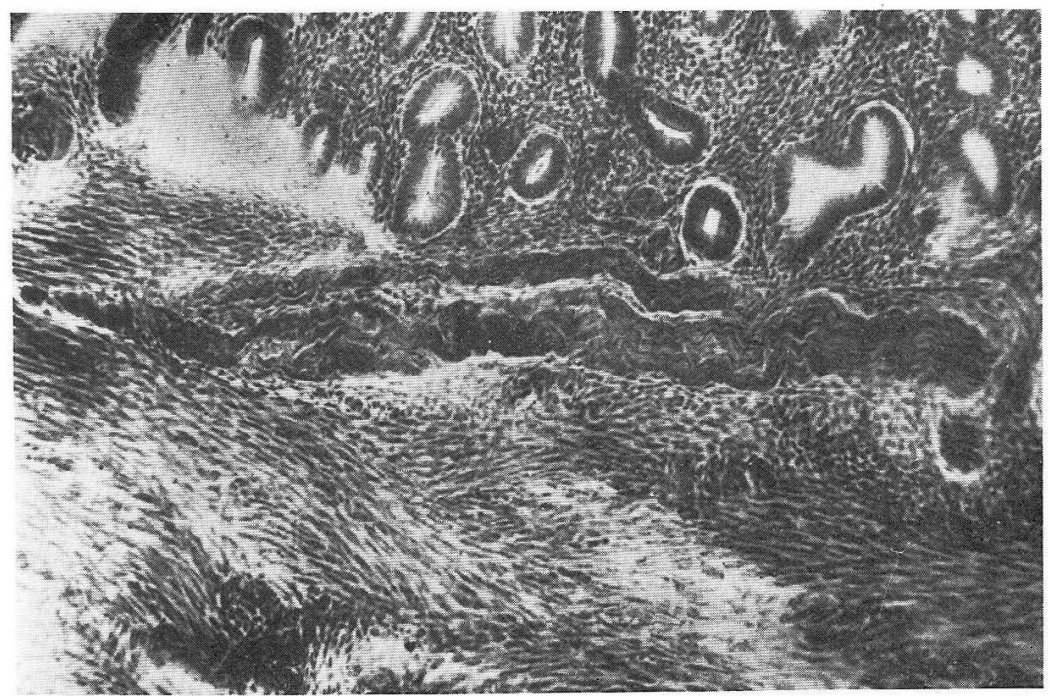

Fig. 10. Photomicrograph of section of uterine wall cut perpendicularly to the endometrial surface. Along the boundary between the endo- and myometrium is found a longitudinal section of a large fiber bundle for a relatively long distance.

Fig. 11. Photomicrograph of a perpendicular section through the endo-myometrial junction of a human uterus. A relatively large bundle of unmyelinated fibers is found to arise upwards through the basement layer of the endometrium.

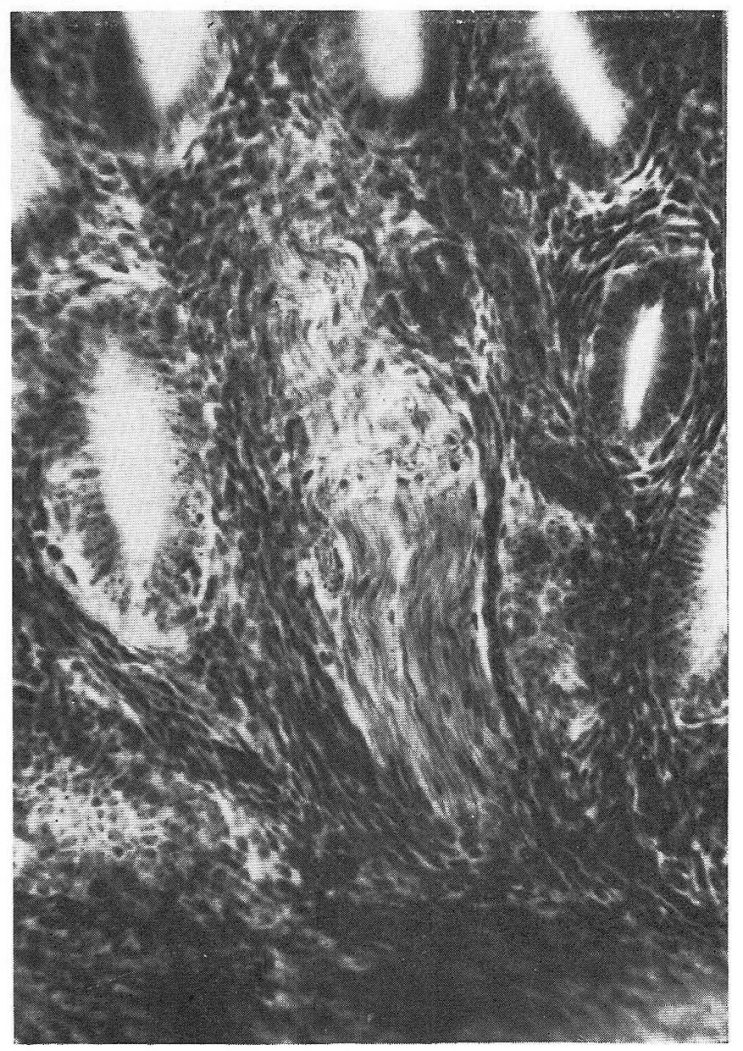




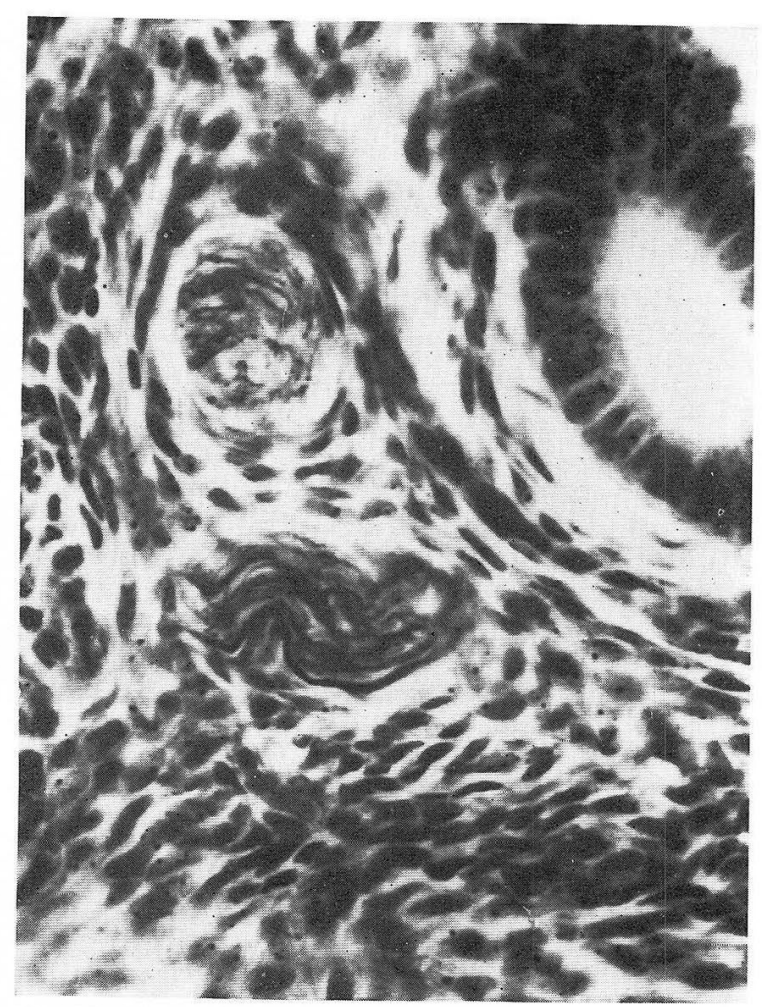

Fig. 12. Photomicrograph of perpendicular section of the endo-myometrial junction of the human uterus, showing two unmyelinated nerve fiber-bundles lying near an uterine gland. One of them was cut transversely, and a nother longitudinally.

endometrium which is separated during the menstruation (Fig. 13).

It is generally accepted that, in the human uterus, the nerve distribution in the endometrium is exclusively limited in its basement layer and absent in the functional layer where the nervous elements can be found only in the embryonic time (OSAKI 1937, KOPPEN 1950, 1952, JABON ERO 1953, and YAMADA et al. 1954). Differences in the endometrial innervation among the animals of primate menstrual and non-primate cycles were discussed by YAMADA et al. (1954).

In this study, the sections in which the upper two thirds of the endometrium showed a nerve supply were obtained of the uterus from a nulliparous woman whose ovary was marked by large cystomas. Hence, the only possible explanation is that the endometrium in this case had undergone atavistical change into an embryonic type. But, these preparations indicated a sufficient developement of the uterine glands and other tissue structures in the endometrium. So, the question remains unsolved.

As to the myelinated nerve distribution in the uterus, there have been many descriptions made by various authors. Recently, YAMADA, WATANABE and 


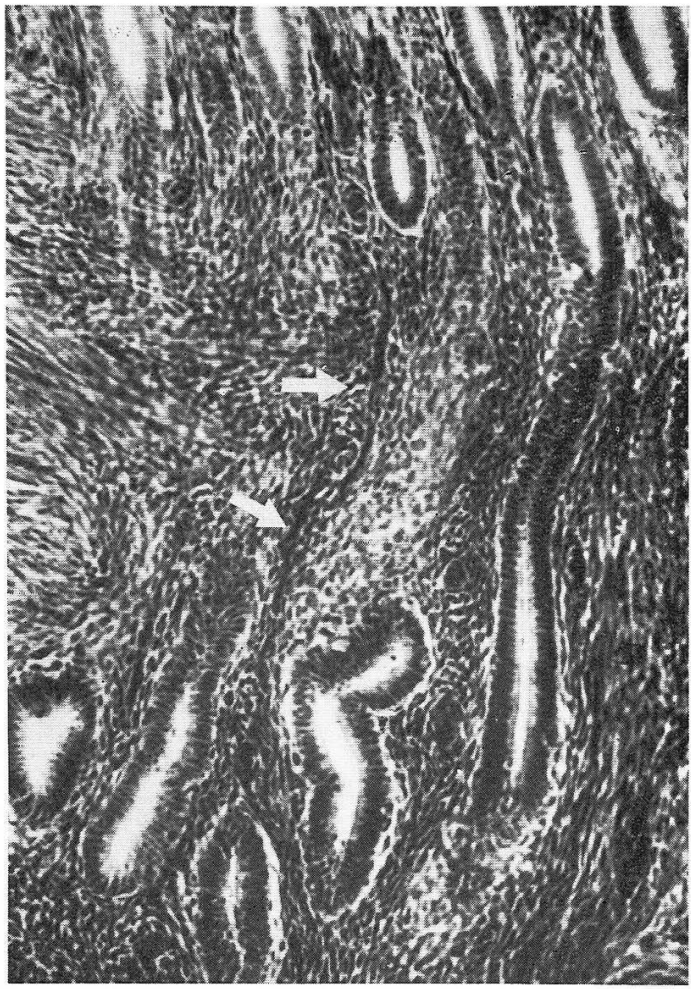

F'g. $13 \mathrm{~A}$ and B. Phothmtcrographs of perpendicular section through the endometrium, in which two nourofibrillar strands are seen passing through the lamina propria parallel to the uterine glands. $\mathbf{B}$ is a high magnification of the same, to emphasize their plexiform arrangement of the neurofibrils in the strands.

MORI (1954) described thick myelinated fibers, and independently thereof, some unbranched and simply branched endings in the myometrium of the canine uteri. The authors supposed them to be sensory in nature. NISHIMURA (1954) observed a few thick fibers ending exclusively in the uterus of fetuses. DUPPROY (1954) described three types of the sensory corpuscles in the uterus of human adults and still-borns. KOPPEN (1952) observed a number of myelinated fibers, which lost their myeline sheaths during their repeated branchings.

In this study, relatively coarse nerve fibers were of ten found in the deepst layer of the endometrium, as well as in the myometrium. However, so far as the corpus and fundus uteri observed in this study are concerned, the coarse fibers were always un-myelinated. Nor was there observed any typical sensory ending.

\section{Discussion.}

A reticular arrangement of the vegetative nerve periphery in the uterus has 


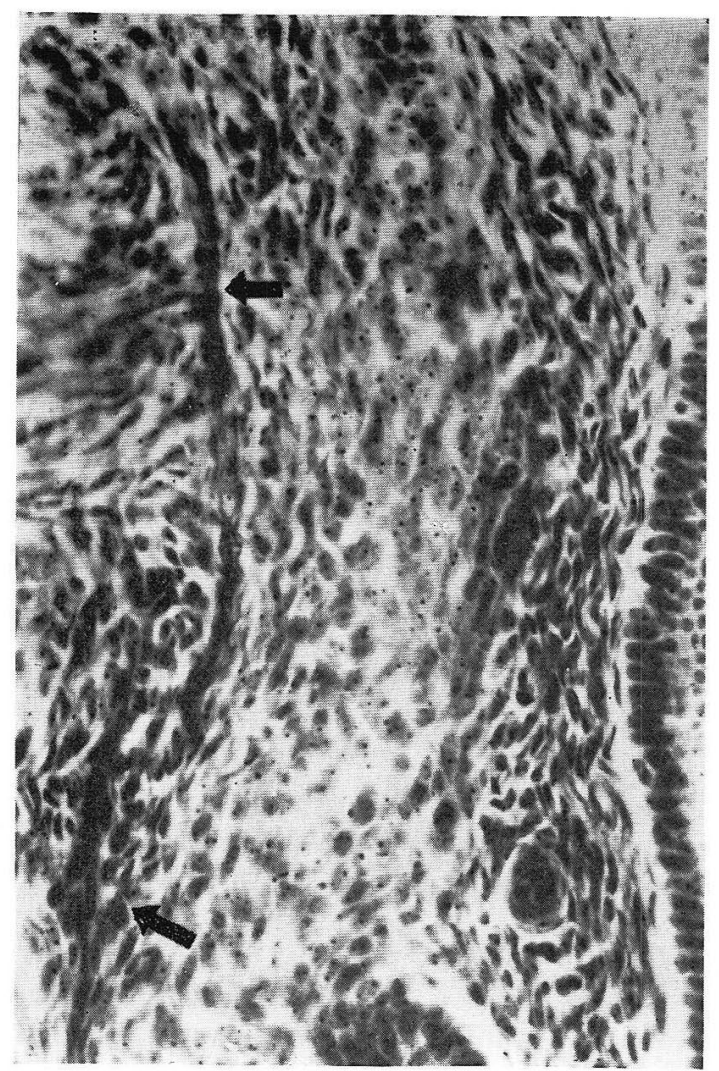

Fig. 13. B.

been discussed with pros and cons by many authors (KNOCHE 1952, KOPPEN 1950, 1952, JABONERO 1953 etc.). The present anatomical acceptance does not seem to leave any room for controversy as to this problem. Thus, the important problems which remain are 1 . the nature of the protoplasm enclosing the neurofibrillar strands and of the so-called interstitial cells, and also the sheath cells, and finally 2 . the relation between the nervous syncytium and the effector cells.

The question whether the protoplasmic strands are of neuronic or lemnoblastic nature and the question on the nature of the interstitial cells were minutely discussed by JABONERO (1952, 1953). But these questions seem to be left unclarified and are still requiring a further investigation. As to the syncytial continuity of the structures of the vegetative nerve periphery, the foregoing descriptions may have given an answer.

The relation of the nervous syncytium to the effector cells is one of the most essential problems in neurohistology. As already mentioned, KOPPEN (1950, 1952) and YAMADA et al. (1954) indicated an 'oberflächlicher Kontakt' and a 'tactile control' of the terminal reticulum upon the supplied cells in the uterus from women and from dogs. In this study, attention was directed to the behavior of the neuro- 
Fgi. 14. Photomicrograph of perpendicular section through the endometrium. In the middle layer of the latter, a bundle of a few relatively coarse nervefibers is seen cut transversely in the immediate vicinity of an uterine gland.
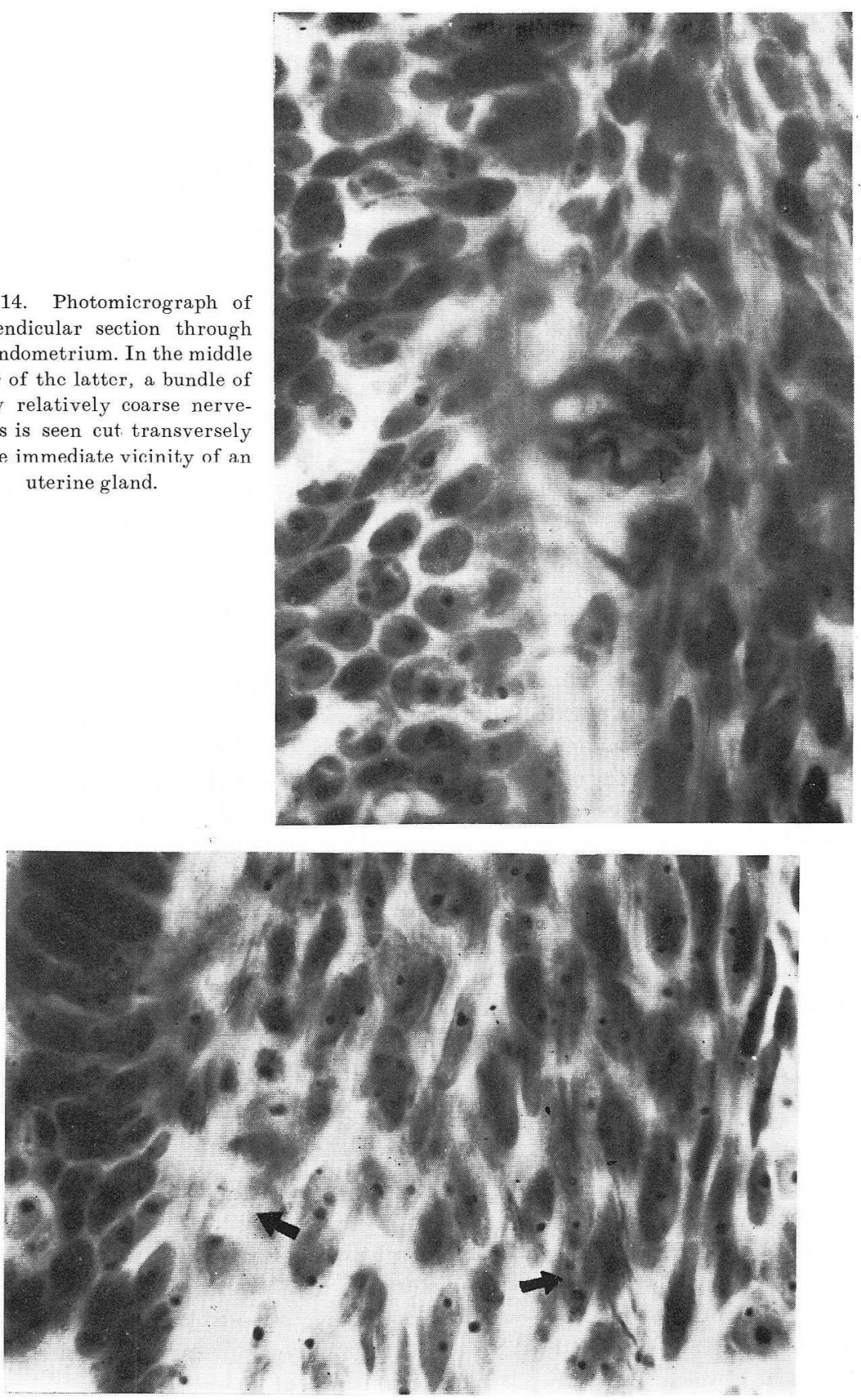

Fig. 15. Photomicrograph of a perpendicular section through the endometrium to show a delicate terminal reticulum (arrows) in the lamina propria. 
plasm, rather than the neurofibril, towards the effector cell. This purpose was fulfiled by the silver method of SUZUKI employed here.

According to JABONERO, the relationship between the distal nervous syncytium and the smooth muscle cell is the so-called 'synapse plexiforme à distance', that is, there run the nerve bands at a short distance from the effector cells. Even a trace of direct contact between the both elements can not be found. Moreover, he strongly denied the existence of the nerves in the muscular coat of the blood vessels as follows: 'Du point de vue strictment morphologique on pourrait affirmer que la tunique musculaire des artères, des veines et des artèrioles manque de toute l'innervation, c'est-à-dire qu'il n'y a pas la moindre trace d'une pénétration de rubans nerveux protoplasmiques ou de fibrills nerveuses (neurofibrilles dégagées du protoplasm nerveux) dans la couche musculaire (1. c., p. 311)'. The lack of a direct connection in this type of synapse is regarded by JABONERO as an argument for the conception of chemical transmission through the un-innervated tissue space. 'Il va sans dire que l'absence de toute connexion directe et intime entre les rubans nerveux et le protoplasme des cellules musculaires, comme il arrive pour les vaisseaux sanguins, vient a l'appui de la notion de la transmisson chimique de l'influx nerveux... (1. c., p. 318).'

In this study, however, the modes of efferent vegetative innervation of the intrinsic uterine and vascular muscles were classified as 'synapses per contiguitatem', which was subclassified into the following two types. One type showed the ultimate periphery of the unmyelinated fibers coming directly through their protoplasmic processes in getting contact with smooth muscle cells. The other type showed the ultimate periphery of the unmyelinated fibers coming in contact with smooth muscle cells via interstitial elements. However, with a present day technique, it is even impossible to draw a line between the neuroplasm enclosing the neurofibrillae and the protoplasm of either the surrounding lemnoblastic or the interstitial elements, although some authors have referred to morphological differences between these elements (P. WALTER and J. TAUBER 1957). They are always in syncytial continuity with each other. From these considerations, it might be more plausible to consider the above mentioned two types of the 'synepses per contiguitatem' as being essentially the same in that their proximal poles of the synapse consist of the peripheral nervous syncytium and present a intimate contact with the effector cells.

\section{Summary.}

The nerve periphery in the human uterus was examined histologically by SUZUKI's improved silver method.

In the myometrium, abundantly distributed vegetative nerve elements form a network of irregular meshes, viz., praeterminal and terminal reticulum. The constituent nerve fibers are composed of protoplasmic strands containing neurofibrils and scattering nuclei of SCHWANN, and argyrophile granules and vacuoles. Along the course of these fibers, there are observed occasinal interstitial cells.

The mode of innervation of the smooth muscle cells of the intrinsic uterine muscle and blood vessels is classified as 'synapse per contiguitatem', in which exist 
two types of its proximal pole of the synaps: 1. the latter consists of neuroplasm of the nerve fibers and directly contacts with the effector cells; 2 . the interstitial cells are situated intermediately between the nerve fibers and the effector cells so that the latters are indirectly connect with the nerve fibers.

In the endometrium, the terminal reticulum of the vegetative nerve periphery spreads out through the basement layer and partly enters the functional layer. The reticulum is observed sometimes being in a close contact with the uterine glands or blood vessels in the propria. Along the endo-myometrial boundary, are very often found relatively large bundles of the un-mylinated nerve fibers.

The authors wish to express their thanks to Prof. K. SUZUKI for his kindly reviewing of an entire artcle and valuable suggestions and encouragements.

\section{内 容 自 抄。}

腔上部摘出による人子宮の售部および底部に於ける神経末梢の形態を鍍銀法に より観察した。主な所見は：

1. 植物神経末梢は終網 terminal reticulum を形成する.

2. 終網の構成繊維に沿って，しばしば interstitial cells が見られる。本細胞 は，細胞質突起を以て上記繊維の原形質鞘と合胞你性に連結する。また，神経繊 維より本細胞の胞佮内へ侵入した若干の神経原繊維が此所で細網を形成する.

3. 植物神経末梢の子宮平滑筋㧍よび血管中膜の平滑筇細胞に対する関係は, 全て synapses per contiguitatem に属するが，乙れらは，該連接の神経極を構成す る要素により, 更に次の 2 種に分類される。即ち，a）1つは，植物神経末梢の原 形質鞘がベール状に拡り，直接に平滑筋細胞と接触する。他は，b）神経末梢が interstitial cell を介して, 間接的に筋細胞と連結する.

4. 子宮内膜に於て植物神経末梢は，基底層は勿論，時には機能層内にも見出 される。乙れらは，固有板組織小に總網を形成し，特に血管および腺管の周囲に しばしば見出される。

5. 筋層内を走行する無髄繊維の太い束が，しばしば内膜に侵入し，乙れと筋 層との境界面に沿って, その最深部を一時通過した後, 再び筋層内に入る.

6. 本研究に用いた低部および底部の材料に於ては，有䯣繊維を見出すことが 出来なかった。

\section{References.}

Dupproy, G.: L'innervation du col uterin chez la femme. C. r. Soc. Biol. Paris. 147 (1953). P. 920-921. - Jabonero, V.: Études sur le systeme neurovegetative périphérique. VII. Le syncytium nerveux intramural de l'uterus humain. Acta anat. 18 (1953). P. 295325. - Knoche, H.: Über die feinere Innervation der Arteria uterina des Menschen. Zugleich ein Beitrag zum Bau der neurovegetativen Endformation. Z. Zellforsch. 37 (1952). S. 205-239.-Koppen, K.: Histologische Untersuchungsergebnisse von der Nervenversorgung 
des Uterus. Arch. Gynäk. 177 (1950). S. 354-391. - Die vegetative Innervation der weiblichen Genitalorganen beim Menschen und ihre psychophysische Problematik. Acta neurovegetativa. 3 (1952). S. $333-334$. - Nelemans, F. A.: Innervation of the small blood vessels. Amer. J. Anat. 83 (1948). P. 43-58. - Nishimura, M.: Innervation of uterus in human embryo. Arch. hist. jap. 6 (1954). P. 233-246. - Oikawa, M.: Sensory innervation of urogenital organs of fourth month female embryo. Tohoku J. exp. Med. 61 (1954). P. 55-66. - Ozaki, M.: Histologische Studien über die peripheren Nerven in den weiblichen Geschlechtsorganen des Menschen. Jap. J. Med. Sci. 6 (1937), S. 225 ; 7 (1937), S. 90. - Pallie, W., C. W. Corner and G. Weddel: Nerve terminations in the myometrium of the rabbit. Anat. Rec. 118 (1954). P. 789-806. - Suzuki, K.: A manual of the histological technique. IV. (Jap). Brain researches (Osaka). 5 (1952). P. 184-192. - Walter, P. and J. Taubert: Zur Frage der Cytoplasmaqualitäten auf der vegetativ-nervösen Endstrecke. Z. Zellforsch. 46 (1957). S. 1-11. - Yamada, M., Y. Watanabe and I. Mori : On the innervation of uterus in dog. Arch. hist. jap. 7 (1954). P. 423-434. 